\title{
SEPTIC ARTHRITIS OF THE SHOULDER AFTER MASTECTOMY AND RADIOTHERAPY FOR BREAST CARCINOMA
}

\author{
K. CHAUdhuRI, D. LONERGAN, I. PORTEK, L. McGUIGAN
}

From St George Hospital and Prince of Wales Hospital, Sydney, Australia

We report five patients who developed septic arthritis of the shoulder after cancer of the ipsilateral breast had been treated by surgery and radiotherapy. Lymphoedema was present in all cases. The infections were not obvious, having subacute onsets, and delays in diagnosis led to destruction of the joint in all but one patient.

J Bone Joint Surg [Br] 1993; 75-B:318-21.

Received 8 April 1992; Accepted 13 July 1992

Breast cancer, the most common malignancy in women, may be treated by surgery, radiotherapy, chemotherapy and endocrine therapy (Henderson et al 1989). Musculoskeletal symptoms are usually suspected to be metastatic in origin.

We present five patients with cancer of the breast who developed septic arthritis in the ipsilateral shoulder. In four of these the diagnosis was delayed because of the unusual presentation and the belief that the pain was due

K. Chaudhuri, MD, Research Fellow in Rheumatology

I. Portek, FRACP, Consultant Rheumatologist

L. McGuigan, MD, FRACP, Staff Specialist in Rheumatology

Department of Rheumatology, The St George Hospital, Belgrave Street, Kogarah, New South Wales 2217, Australia.

D. Lonergan, FRACP, Radiotherapist

Department of Radiotherapy, Prince of Wales Hospital, High Street,

Randwick, Sydney, New South Wales 2031, Australia.

Correspondence should be sent to Dr L. McGuigan.

(C)1993 British Editorial Society of Bone and Joint Surgery 0301-620X/93/2514\$2.00 to metastatic disease or a complication of the radiotherapy treatment. Prompt diagnosis of this previously unreported complication of breast cancer is important since it can be cured by early treatment.

\section{CASE REPORTS}

Detailed case histories are given; they are summarised in Tables I and II.

Case 1. In 1978 at the age of 48, a diagnosis was made of infiltrating adenocarcinoma of the right breast; clinical stage $T_{2} N_{1} M_{0}$. After radical mastectomy, wound healing was delayed by a Staphylococcus aureus infection. Radiotherapy was given later to the internal mammary chain, chest wall and supraclavicular lymph nodes of the affected side, and chemotherapy with LACT (a combination of chlorambucil, methotrexate, 5-fluorouracil and thiotepa) for 12 months, followed by melphalan for six months. The patient had persistent lymphoedema of the right arm for which a lymphovenous anastomosis was attempted two years after the mastectomy.

In February 1981, the patient was admitted to hospital with a painful right shoulder. Radiographs were normal, but a ${ }^{99 \mathrm{~m}} \mathrm{Tc}$ bone scan showed an increased uptake over the right humerus and clavicle. Aspiration of the right shoulder produced a brown fluid which revealed no organisms on Gram staining, but grew Staphylococcus aureus on indirect culture: this was thought to be a contaminant. Pain continued with progressive loss of range of movement of the right shoulder. She remained afebrile, with no lymphadenopathy or involvement of any other joint. She was readmitted six months later and at open biopsy there was frank pus in the shoulder, containing Staphylococcus aureus. Radiographs showed gross destruction of the humeral head (Fig. 1) and treatment was by intravenous flucloxacillin for six weeks and physiotherapy. A radiograph in 1988 showed complete loss of the humeral head (Fig. 2).

Case 2. At the age of 47 , this patient had a modified 
radical mastectomy for right-sided adenocarcinoma, followed by radiotherapy and tamoxifen $10 \mathrm{mg} / \mathrm{day}$. More details are not available, but 13 years later she was admitted with a four-year history of recurrent, intermittent pain and progressive loss of movement of her right shoulder. She gave a history of three episodes of discharge of pus from that shoulder, treated with oral antibiotics.

On admission there were no discharging sinuses or scars to suggest underlying osteomyelitis or abscess. Radiographs showed patchy osteoporosis, sclerotic changes and erosion of the humeral head (Fig. 3) and a CT scan confirmed irregularities on the articular surface and a mottled appearance of the bones (Fig. 4). The possibility of secondary deposits was considered and a $99 \mathrm{~m}$ Tc bone scan showed increased uptake (Fig. 5). A Craig needle biopsy revealed no malignancy, but grew streptococcus group B. The patient responded well to intravenous flucloxacillin and physiotherapy, and was pain-free six months later.

Case 3. At the age of 57, a left radical mastectomy had been performed for a tumour at stage $T_{2} N_{x} M_{x}$. Radiotherapy had been given to the affected internal mammary chain and chest wall, with sparing of the axilla. Twoand-a-half years later she developed pain and stiffness of the left shoulder, but a radiograph showed no bony abnormality, no osteoporosis and no loss of joint space. A ${ }^{99} \mathrm{~m}$ Tc bone scan suggested an inflammatory arthritis or septic arthritis. Arthroscopy showed adhesions and a small amount of pus was obtained. Gram staining showed no organisms but culture grew a group $\mathrm{C}$ streptococcus.

The patient responded well to intravenous flucloxacillin $12 \mathrm{~g} /$ day for two weeks, followed by oral cephalexin

Table I. Clinical features of five patients with septic arthritis after treatment for carcinoma of the breast. All had surgery and radiotherapy followed by lymphoedema

\begin{tabular}{|c|c|c|c|c|c|c|c|}
\hline Patient & $\begin{array}{l}\text { Age at diagmosis } \\
\text { of breast } \\
\text { carcinoma (yr) }\end{array}$ & $\begin{array}{l}\text { Breast } \\
\text { carcinoma }\end{array}$ & $\begin{array}{l}\text { Onset of septic } \\
\text { arthritis (yr) }\end{array}$ & Chemotherapy & $\begin{array}{l}\text { Delay before } \\
\text { septic arthritis } \\
\text { diagnosed }\end{array}$ & Treatment & Outcome \\
\hline 1 & 48 & $\begin{array}{l}\text { Infiltrating } \\
\text { adenocarcinoma } \\
T_{2} N_{1} M_{0}\end{array}$ & 51 & LACT * & $7 \mathrm{mth}$ & $\begin{array}{l}\text { Intravenous } \\
\text { flucloxacillin } \\
\text { Physiotherapy }\end{array}$ & $\begin{array}{l}\text { Destruction of } \\
\text { shoulder }\end{array}$ \\
\hline 2 & 47 & Adenocarcinoma & 60 & $\begin{array}{l}\text { Tamoxifen } \\
10 \mathrm{mg} / \text { day }\end{array}$ & $4 \mathrm{yr}$ & $\begin{array}{l}\text { Intravenous } \\
\text { flucloxacillin } \\
\text { Physiotherapy }\end{array}$ & $\begin{array}{l}\text { Destruction of } \\
\text { shoulder }\end{array}$ \\
\hline 3 & 57 & $\begin{array}{l}\text { Intraductal } \\
\text { adenocarcinoma } \\
T_{2} N_{x} M_{x}\end{array}$ & 60 & No & 11 days & $\begin{array}{l}\text { Intravenous } \\
\text { flucloxacillin }\end{array}$ & $\begin{array}{l}\text { Almost complete } \\
\text { recovery }\end{array}$ \\
\hline 4 & 71 & $\begin{array}{l}\text { Poorly } \\
\text { differentiated } \\
\text { adenocarcinoma } \\
\mathrm{T}_{3} \mathrm{~N}_{10} \mathbf{M}_{0}\end{array}$ & 74 & No & $4 \mathrm{mth}$ & $\begin{array}{l}\text { Intravenous } \\
\text { flucloxacillin }\end{array}$ & $\begin{array}{l}\text { Marked restriction of } \\
\text { movement }\end{array}$ \\
\hline 5 & 59 & $\begin{array}{l}\text { Scirrhous } \\
\text { carcinoma } \\
T_{3} N_{16} M_{0}\end{array}$ & 65 & No & 15 days & $\begin{array}{l}\text { Intravenous Keflin } \\
\text { followed by oral } \\
\text { erythromycin }\end{array}$ & $\begin{array}{l}\text { Marked restriction of } \\
\text { movement }\end{array}$ \\
\hline
\end{tabular}

* combination chemotherapy consisting of chlorambucil, methotrexate, 5-fluorouracil and thiotepa

Table II. Laboratory findings in five patients with septic arthritis after treatment for carcinoma of the breast

\begin{tabular}{|c|c|c|c|c|}
\hline Patient & Haematology & Radiology & Bone scan & Microbiology \\
\hline 1 & $\begin{array}{l}\mathrm{Hb}: 11.3 \mathrm{~g} / 100 \mathrm{ml} \\
\mathrm{WCC}: 7700 / \mathrm{mm}^{3} \\
\text { ESR : } 114 \mathrm{~mm} / \mathrm{hr}\end{array}$ & $\begin{array}{l}\text { Normal shoulder at onset. Seven } \\
\text { months later, destruction of humeral } \\
\text { head }\end{array}$ & $\begin{array}{l}99 \mathrm{~m} \text { Tc increased uptake humerus and } \\
\text { clavicle. Gallium scan: moderate non- } \\
\text { specific uptake }\end{array}$ & $\begin{array}{l}\text { Delayed growth of Staphylococcus } \\
\text { aureus. Seven months later, } \\
\text { Staphylococcus aureus }\end{array}$ \\
\hline 2 & $\begin{array}{l}\mathrm{Hb}: 12.6 \mathrm{~g} / 100 \mathrm{ml} \\
\mathrm{WCC}: 5100 / \mathrm{mm}^{3} \\
\text { ESR: } 10 \mathrm{~mm} / \mathrm{hr}\end{array}$ & $\begin{array}{l}\text { Patchy osteoporosis and sclerotic } \\
\text { changes. Erosive defect. CT scan: } \\
\text { irregularities of humeral head, mottled } \\
\text { appearance of bones }\end{array}$ & Increased ${ }^{99 m} \mathrm{Tc}$ uptake of shoulder & $\begin{array}{l}\text { Craig needle biopsy: streptococcus } \\
\text { group B }\end{array}$ \\
\hline 3 & $\begin{array}{l}\mathrm{Hb}: 13.3 \mathrm{~g} / 100 \mathrm{ml} \\
\mathrm{WCC}: 9000 / \mathrm{mm}^{3} \\
\text { ESR: } 125 \mathrm{~mm} / \mathrm{hr}\end{array}$ & $\begin{array}{l}\text { No bony abnormalities, no loss of joint } \\
\text { space, no osteoporosis }\end{array}$ & $\begin{array}{l}99 \mathrm{~m} \text { Tc scan highly suggestive of } \\
\text { inflammatory arthritis consistent with } \\
\text { septic arthritis }\end{array}$ & $\begin{array}{l}\text { Aspirate: inconclusive. Arthrotomy: } \\
\text { drainage of pus; Gram stain negative } \\
\text { indirect growth of streptococcus } \\
\text { group C }\end{array}$ \\
\hline 4 & $\begin{array}{l}\mathrm{Hb}: 11.6 \mathrm{~g} / 100 \mathrm{ml} \\
\mathrm{WCC}: 11000 / \mathrm{mm}^{3} \\
\text { ESR: } 111 \mathrm{~mm} / \mathrm{hr}\end{array}$ & $\begin{array}{l}\text { No bony abnormality. After fall while } \\
\text { in hospital: radiographs showed } \\
\text { fracture of humeral head. No evidence } \\
\text { of septic arthritis }\end{array}$ & $\begin{array}{l}\text { Increased }{ }^{99 m} \mathrm{Tc} \text { uptake in shoulder } \\
\text { capsule }\end{array}$ & $\begin{array}{l}\text { Aspirate: blood, no pus, negative } \\
\text { culture. Arthrotomy: Staphylococcus } \\
\text { epidermidis }\end{array}$ \\
\hline 5 & $\begin{array}{l}\mathrm{Hb}: 13.1 \mathrm{~g} / 100 \mathrm{ml} \\
\mathrm{WCC}: 11000 / \mathrm{mm}^{3} \\
\text { ESR: } 115 \mathrm{~mm} / \mathrm{hr}\end{array}$ & $\begin{array}{l}\text { At onset of symptoms: normal } \\
\text { shoulder. One month later: destruction } \\
\text { of humeral head }\end{array}$ & $\begin{array}{l}\text { Ill-defined increase of }{ }^{99} \mathrm{~m} \mathrm{Tc} \text { uptake in } \\
\text { upper humerus. Gallium scan: } \\
\text { increased accumulation in shoulder } \\
\text { suggesting an abscess }\end{array}$ & $\begin{array}{l}\text { Arthrotomy: Staphylococcus aureus } \\
\text { Blood culture: Staphylococcus aureus }\end{array}$ \\
\hline
\end{tabular}


$1 \mathrm{~g} /$ day for six months. With intensive physiotherapy she recovered a full range of movement.

Case 4. At the age of 71 , the diagnosis of a $T_{3} N_{1 b} M_{0}$, poorly differentiated, adenocarcinoma of the left breast was made and treated by modified radical mastectomy and radiotherapy. Three years later the patient gave a four-month history of pain and restriction of movement in the left shoulder, but had no pyrexia, weight loss, or lymphadenopathy. There was some wasting of the shoulder girdle with lymphoedema of the arm. Radiographs were normal, but a bone scan showed an increased uptake at the left shoulder. Aspiration produced blood but no pus, and a provisional diagnosis of capsulitis was made.

While in hospital the patient fell and fractured her left shoulder, and arthrotomy revealed septic arthritis and osteomyelitis. Cultures grew Staphylococcus epider- midis and there was no evidence of malignancy on histopathological examination of biopsy specimens.

Case 5. At the age of 59 this patient had a $T_{3} N_{1 b} M_{0}$ scirrhous carcinoma of the left breast treated by radical mastectomy and radiotherapy to the left supraclavicular nodes, internal mammary chain, chest wall and axilla. She also had one cycle of LACT (see case 1), which was not continued because of bone-marrow suppression.

Six years later she was admitted with a one-week history of pain and stiffness of the left shoulder. There was gross swelling of the left arm and a low-grade fever which later spiked to $39^{\circ} \mathrm{C}$. A provisional diagnosis of left axillary venous thrombosis was made, but radiographs including digital subtraction angiography and venography were all normal. A ${ }^{99 \mathrm{~m} T c}$ bone scan showed increased uptake in the left upper humerus which was thought to be of doubtful significance. Dynamic and

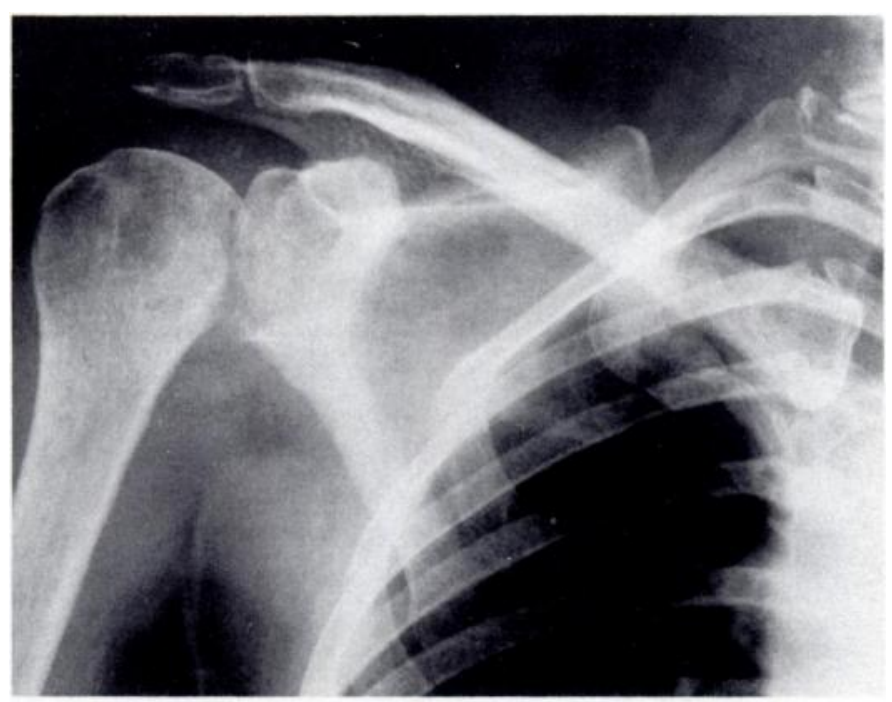

Fig. 1

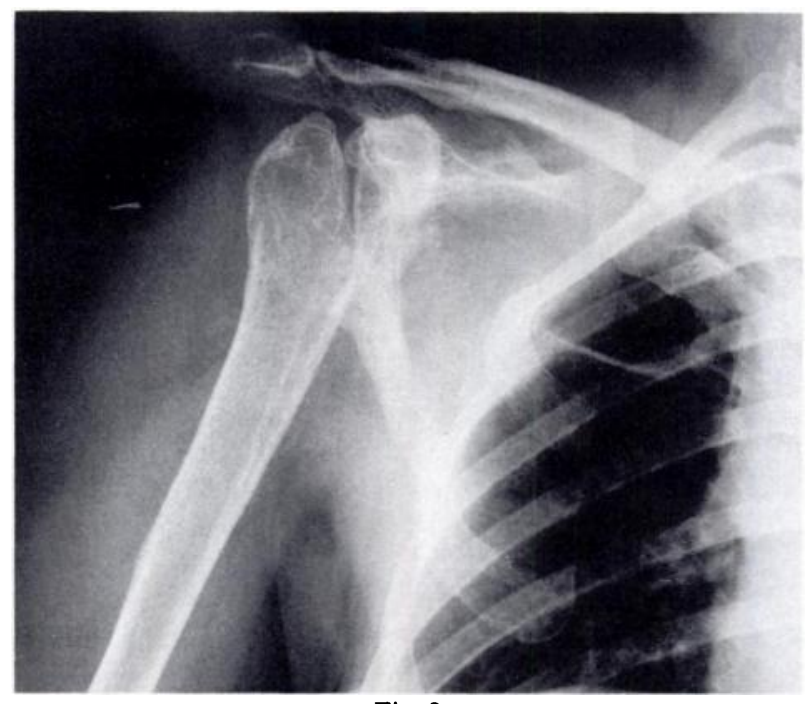

Fig. 2

Case 1. Figure 1 - Radiograph of the right shoulder six months after the onset of pain showing a severely damaged humeral head. Figure 2 Radiograph of the right shoulder seven years after the onset of shoulder pain. The humeral head is completely destroyed.

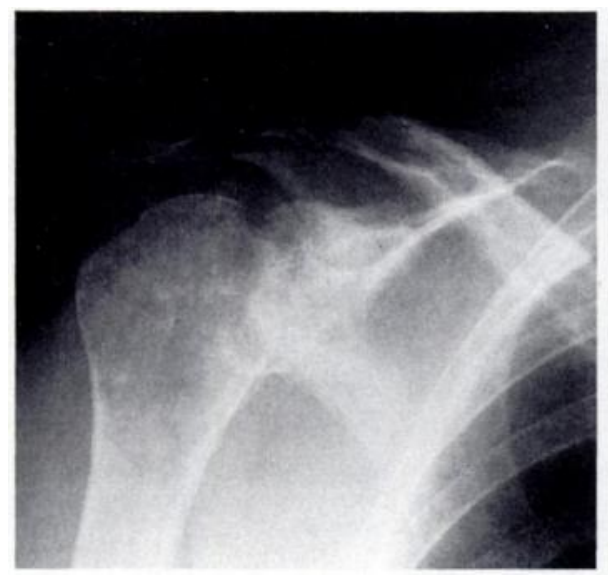

Fig. 3

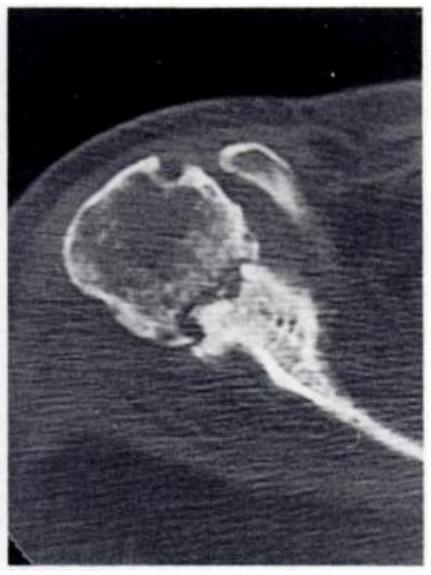

Fig. 4

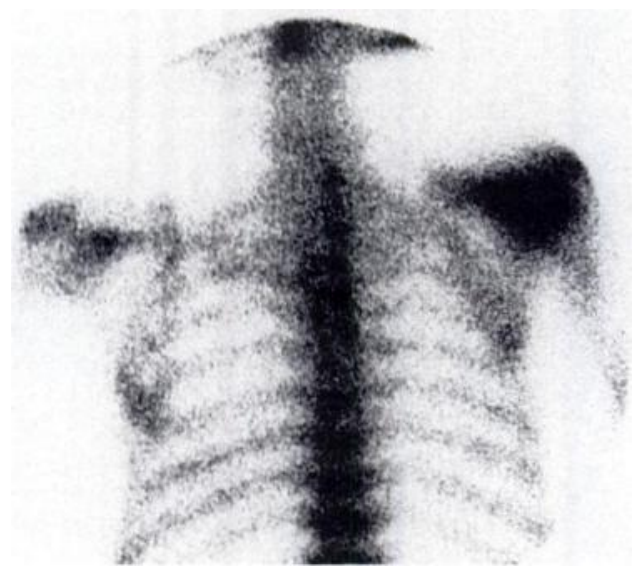

Fig. 5

Case 2. Figure 3 - Radiograph of the right shoulder showing patchy osteoporosis and sclerotic changes in the humeral head. Figure 4 - A CT scan of the same shoulder showing irregularities of the articular surface of the glenoid and humeral head. Figure $5-A^{99 m}$ Tc bone scan showing grossly increased uptake in the right shoulder. 
blood pool scans showed mildly increased tracer uptake 2.5 hours after injection. A gallium scan showed increased accumulation in the left shoulder with a 'halo' effect in the proximal humeral region suggesting an abscess. At arthrotomy, an abscess was drained, and the pus grew Staphylococcus aureus. The same organism was isolated from blood cultures two weeks later. Despite high dose parenteral and oral antibiotics for several months, the patient continued to have stiffness and pain which necessitated arthrodesis of the shoulder eight months later.

\section{DISCUSSION}

All our five cases of septic arthritis of the shoulder occurred in women with breast cancer on the same side, all treated by both surgery and radiotherapy. Four of the five patients had destruction of the joint, and in all four the diagnosis had been delayed by the failure to recognise that sepsis was a possible cause of symptoms, and the failure to perform the correct investigations. The attending clinicians could be criticised for these failures, but the subacute onset, the presence of lymphoedema and the lack of significant fever in three of the five cases made the initial diagnosis difficult (Goldenberg and Cohen 1976).

In several cases, metastatic breast disease was thought to be the cause of the pain, but continued followup has revealed no sign of tumour recurrence in any of them. In all five patients, radionecrosis was thought to be contributing to the pain, thereby making any invasive investigation seem more hazardous because of poor skin healing after irradiation (Brady, Binnick and Fitzpatrick 1987; Dalinka and Neustadter 1988). Although radionecrosis may occur in up to $3 \%$ of patients irradiated for breast cancer the incidence is falling as a result of better techniques (Howland et al 1975; Dalinka and Neustadter 1988). Radiation necrosis of the humerus may be detected at 7 to 10 years after therapy, but associated findings in the ribs, clavicle and scapula are frequent and may help in the diagnosis (Dalinka and Neustadter 1988). There were no such changes in the ribs, clavicle or scapula in any of our patients.

Infection is widely recognised as a complication of malignancy but we have not been able to find any reports of septic arthritis after the treatment of carcinoma of the breast. It has been reported in association with leukaemia (Appelbaum and Dossett 1982), multiple myeloma (Miller, Hoppmann and Pisko 1988) and colonic carcinoma (Lyons and Nevins 1979), but all these cases either had an active tumour or were undergoing chemotherapy when septic arthritis developed. Only two of the five patients in our study had had any form of chemotherapy and this was adjuvant only. None of the patients developed infection at other sites, indicating that they were unlikely to have generalised immunological compromise. None of them had had an intra-articular injection of steroid or any underlying systemic disorder such as diabetes.

We cannot be certain that the breast neoplasia or its treatment were causally related to the development of the septic arthritis, but this seems likely, particularly as septic arthritis of the shoulder is unusual in elderly women (Goldenberg 1989). A number of mechanisms can be postulated. The radiotherapy notes of three of the five patients recorded that the shoulder was included in the field of treatment, and in the other two patients this was likely but could not be confirmed since the notes were not available. Radiotherapy may have damaged the tissues of the joint although the characteristic features of radionecrosis were absent (Dalinka and Neustadter 1988), and these damaged tissues may have provided a site for colonisation following bacteraemia. In addition, host-defence mechanisms may have been compromised by irradiation-induced damage and by the lymphatic stasis of lymphoedema.

We present these cases to draw attention to the clinical importance of the association between breast cancer and sepsis. We acknowledge the difficulties of diagnosis and management, and in particular the reluctance to perform invasive investigations in a region exposed to radiotherapy. The early detection and treatment of septic arthritis in these patients are important, since prompt treatment can effect a cure.

We acknowledge the help of J. Bertouch MD, FRACP and P. Youssef MB BS of the Department of Rheumatology, Prince Henry and Prince of Wales Hospitals, Sydney.

No benefits in any form have been received or will be received from a commercial party related directly or indirectly to the subject of this article.

\section{REFERENCES}

Appelbaum PC, Dossett JH. Arthritis caused by unidentified grampositive rods in a child with acute lymphocytic leukaemia. J Clin Microbiol 1982; 15:525-7.

Brady LW, Binnick SA, Fitzpatrick PJ. Skin cancer. In: Perez CA, Brady LW, eds. Principles and practice of radiation oncology. London, etc: J.B. Lippincott Co, 1987:377-94.

Dalinka MK, Neustadter LM. Radiation changes. In: Resnick D, Niwayama G, eds. Diagnosis of bone and joint disorders. Second ed. Philadelphia, etc: W. B. Saunders Co, 1988:3025-56.

Goldenberg DL. Bacterial arthritis. In: Kelley WN, Harris ED, Ruddy S, Sledge CB, eds. Textbook of rheumatology. Philadelphia, etc: W. B. Saunders Co, 1989:1567-85.

Goldenberg DL, Cohen AS. Acute infectious arthritis. Am J Med 1976; 60:369-77.

Henderson IC, Harris JR, Kinne DW, Hellman S. Cancer of the breast. In: DeVita VT, Hellman S, Rosenberg SA, eds. Cancer: principles \& practice of oncology. Third ed. Philadelphia, etc: J. B. Lippincott Co, 1989:1197-268.

Howland WJ, Loefiler RK, Starchman DE, Johnson RG. Postirradiation atrophic changes of bone and related complications. Radiology 1975; 117:677-85.

Lyon LJ, Nevins MA. Carcinoma of the colon presenting as pyogenic arthritis. JAMA 1979; $241: 2060$.

Miller MI, Hoppmann RA, Pisko EJ. Multiple myeloma presenting with primary meningococcal arthritis. Am J Med 1987; 82:1257-8 